УдК 621.391

\title{
МЕТОД РАСЧЕТА ПАРАМЕТРОВ РАДИОКАНАЛА БЕСПРОВОДНОГО ДОСТУПА К МОБИЛЬНЫМ ТЕРМИНАЛАМ В МИЛЛИМЕТРОВОМ ДИАПАЗОНЕ
}

\author{
СУНДУЧкОВ к.С., ГОЛИК А.Л., ВОЛкОв С.Э., ЯЩУК А.С., СУНДУЧкОВ И.к.
}

\author{
Институт телекоммуникационных систем национального технического университета Украинь \\ «Киевский политехнический институт», \\ Украина, Киев, 03056, пр-т Победы 37
}

\begin{abstract}
Аннотация. Предложен ряд новых технических решений, позволяющих реализовать доставку сигналов мультимедиа услуг 4G со скоростью передачи данных 6-12 Мбит/с для каждого из абонентов, которые движутся со скоростью 300-350 км/ч при общей емкости сети более тысячи абонентов. Разработана архитектура раздаточной сети в миллиметровом диапазоне длин волн. Выведено уравнение энергетического баланса радиоканала, которое представляет собой основу метода расчета параметров радиоканала для сети такого типа. Приведены примеры расчета параметров радиоканала беспроводного доступа к мобильным терминалам в миллиметровом диапазоне
\end{abstract}

Ключевые слова: качество приема; скорость передачи данных; скорость движения абонента; емкость сети

\section{1. ВВЕДЕНИЕ}

В мобильной связи при движении мобильного терминала (МТ) при переходе из соты в соту осуществляется процедура хэндовера. Время, необходимое для реализации процедуры хэндовера, ограничивает скорость движения МТ и скорость передачи данных. В [1] предложено объединить несколько сот в одну и тем самым предоставить МТ возможность реже осуществлять процедуру хэндовера. В [2] с этой же целью предложено создать «скользящую» вдоль трассы соту. Эти решения позволяют незначительно увеличить допустимую скорость движения МТ при приеме сигналов услуг.

Сегодня на автобанах Германии при скорости движения МТ до 200 км/ч обеспечивается связь на уровне услуг $3 \mathrm{G}$ с помощью сетей LTE и UMTS. Достигнутые скорости передачи данных для мобильных абонентов в самолетах $(900$ км/ч), в поездах (300 км/ч) и по автобану (200 км/ч) составляют $0,5-3,3-10,14-150$ Мбит/с, соответственно [2-9]. Эти и другие источники $[10,11]$ отмечают, что приведенные результаты получены для систем связи $3 \mathrm{G} \mathrm{LTE}$ и UMTS.

В последнее время в КНР фирмой ТD Industry Alliance ведутся разработки TD-LTE 2012 (Time Division Long Term Evolution), в которой используется асимметричный канал для двухсторонней связи по принципу временного разделения [12].

В период с ноября 2004 до 2010 года в Китае на базе современных технологий разработано 10 версий TD-LTE технологии. Версия 10 предполагает несколько новых технических решений для повышения производительности системы, среди которых объединение поднесу- 